\title{
Relationship between Physical Environment and Smoking Behaviour with Accute Respiratory Infection in Class-| Correctional Institutions in Lowokwaru, Malang
}

\author{
Devia Laily Trisnaningdyah ${ }^{1}$, Supriyadi ${ }^{2}$, and Muhammad Al-\|rsyad ${ }^{1}$ \\ 'Department of Public Health, Faculty of Sport Science, Universitas Negeri Malang, Malang, \\ Indonesia \\ ${ }^{2}$ Faculty of Sport Science, Universitas Negeri Malang, Malang, Indonesia
}

ORCID:

Muhammad Al-Irsyad: https://orcid.org/0000-0003-1174-4075

\section{Abstract}

Many prisoners experience Accute Respiratory Infection (ARI), and as many as 5,000 new cases are reported every year. This is generally caused by the prisoners' inadequate physical environment and smoking behaviour. This observational analytical

Corresponding Author: Muhammad Al-Irsyad muhammad.irsyad.fik@um.ac.id

Published: 25 March 2021

Publishing services provided by Knowledge E

(c) Devia Laily Trisnaningdyah et al. This article is distributed under the terms of the Creative Commons Attribution License, which permits unrestricted use and redistribution provided that the original author and source are credited.

Selection and Peer-review under the responsibility of the ISMoPHS 2020 Conference Committee. study was conducted using a cross-sectional design over a duration of two months, from December 2019 to January 2020. The independent variables in this study included occupancy density, ventilation, temperature, humidity, lighting and prisoners' smoking behaviour on a nominal scale, while the dependent variable included the incidence of ARI with a nominal scale. A total of 96 prisoners who were positive for ARI and visited the Class-1 Prison Clinic of Lowokwaru, Malang were selected using the sampling estimation method. While a univariate analysis was used to explain the characteristics of each variable in the study, a bivariate analysis was done to determine the relationship between the independent and dependent variables using the contingency coefficient test. The results of the study indicated that there was a significant relationship between the occupancy density, ventilation, temperature, humidity and lighting, and the incidence of ARI, but no significant relationship was noted between the prisoners' smoking behaviour and the incidence of ARI in Class-1 prisons of Lowokwaru, Malang.

Keywords: physical environment, smoking behaviour, ARI

\section{Introduction}

The main problems and often occur are health problems related to the physical environment, and the current state of the prison is overcapacity (overcrowding) and inadequate physical environmental conditions. According to data obtained from the correctional database system in September 2019, there are 3,109 residents in the Class I Prison of Lowokwaru Malang [1]. As a result, there was an over capacity of $232 \%$ [2]. This condition 
can cause new problems that occur in prisons, especially in health problems. Based on the initial study conducted by the author on November 5, 2019, information was obtained about the 5 highest diseases in Class I Lowokwaru Malang Prison including skin diseases such as (scabies, dermatitis), ARI, toothache, hypertension and other diseases such as (dizziness, fractures, diarrhoea). For ARI diseases throughout 2019 from January to October which have been recorded in the clinical visit book of the Class I Lowokwaru Malang Prison, totalling 5,463 cases. Based on the description of the problem above, it is explained that the density of occupancy, ventilation, air quality, lighting and smoking behaviour are factors that influence the occurrence of ARI disease. So that the authors are interested in conducting research on these problems. The research entitled "The Relationship between Physical Environmental Conditions and Smoking Behaviour with the incidence of ARI in Class 1 Lapas Lowokwaru Malang".

\section{Material and Method}

This research is a descriptive observational analytic study. This study aims to determine the relationship between environmental conditions and smoking behaviour with the incidence of ARI. The design used in this study is cross-sectional, this design is to determine the cause and effect variables of cases that occur in the object of research which are measured and collected at the same time [3] . The population in this study were all prisoners who came to visit the prison clinic and tested positive for ARI from December 2019 to January 2020 at the Class 1 Prison in Lowokwaru Malang. Determination of the sample using sample estimation, due to not knowing the population, the sample estimate for the cross sectional study of [4] Lameslow et al., Obtained a research sample of 96 samples, which are prisoners inmates of Class 1 Lowokwaru Malang prisons who were positive for ARI during the study period this. The sampling technique used in this study was quota sampling by determining the number of samples in advance or setting a quotum (quota) [4]. Then the ration is used as the basis for sampling, if the number of samples is met, then no more sampling can be done. Basis for taking $\mathrm{n}$ data in this study using interviews related to the smoking behaviour of inmates who tested positive for ISPA. Observations to be made include occupancy density, ventilation, temperature, humidity and lighting.

\section{Results}




\subsection{Characteristics of respondents}

All respondents that participated in this study were male (100\%). The majority of them were late teen (42.7\%) and 29.2 of them were early adult. It indicated that most of them were classified as productive age group. Based on the room or block that was occupied in the prison, most of respondents came from block C (32.3\%). Almost a half of total respondents (41.7\%) had graduated from senior high school. Their employment status was mostly entrepreneur (55.2\%). All respondents were active smoker. Majority of them were a light smoker (53.1). The characteristics of respondent could be seen in Table 1.

TABLE 1: Distribution of respondent's characteristics.

\begin{tabular}{l} 
Variable \\
Sex \\
Male \\
Female \\
Age \\
Late teen \\
Early adult \\
Late adult \\
Early elderly \\
Late elderly \\
Room (block) \\
A \\
B \\
C \\
D \\
Educational level \\
Primary school \\
Junior high school \\
Senior high school \\
Higher education \\
Employment \\
Farmer \\
Entrepreneur \\
Civil servant \\
Student \\
Others \\
Smoking behaviour \\
Light \\
Moderate \\
Heavy \\
\hline Source:Author's \\
\hline
\end{tabular}

\begin{tabular}{|c|c|}
\hline Number (n) & Percentage (\%) \\
\hline 96 & 100 \\
\hline 0 & 0 \\
\hline 41 & 42.7 \\
\hline 28 & 29.2 \\
\hline 17 & 17.7 \\
\hline 7 & 7.3 \\
\hline 3 & 3.1 \\
\hline 15 & 15.6 \\
\hline 27 & 28.1 \\
\hline 31 & 32.3 \\
\hline 23 & 24 \\
\hline 24 & 25 \\
\hline 28 & 29.2 \\
\hline 40 & 41.7 \\
\hline 4 & 4.2 \\
\hline 26 & 27.1 \\
\hline 53 & 55.2 \\
\hline 4 & 4.2 \\
\hline 1 & 1 \\
\hline 12 & 12.5 \\
\hline 51 & 53.1 \\
\hline 36 & 37.5 \\
\hline 9 & 9.4 \\
\hline
\end{tabular}

Source: Author's own work. 


\subsection{Characteristics of physical environment}

Table 2 showed the physical environment measurements of the rooms that were occupied by the respondents. The floor area of a room in one room is divided by the number of occupants of 1 prison room with the criteria, fulfilling the requirements if the room area is $5,4 \mathrm{~m}^{2}$ for one occupant and does not meet the requirements if the room area is $<5,4 \mathrm{~m}^{2}$ for one occupant. A total of 86 respondents did not meet the requirements and 10 people met the requirements, it means that the density of occupancy in the Class 1 Prison of Lowokwaru Malang mostly did not meet the requirements (densely occupied). The room ventilation of respondents in this study was divided into two categories, namely $<10 \%$ of the floor area and $\geq 10 \%$ of the floor area. A total of 86 respondents experienced room ventilation that did not meet the requirements and as many as 10 respondents met the requirements, so that the occupancy ventilation in the Class 1 Prison in Lowokwaru Malang mostly did not meet the requirements. The temperature in the respondent's residence meets the requirements if it is between $18^{\circ} \mathrm{C}$ to $30^{\circ} \mathrm{C}$. There are 86 respondents whose occupancy temperature does not meet the requirements and 10 respondents who meet the requirements. So that the temperature in the room of the prisoners' residence in the Class 1 Correctional Institution of Lowokwaru Malang mostly does not meet the requirements. The humidity in the room of the respondent meets the requirements if it is between $40 \%-70 \%$. There were 86 respondents whose occupancy humidity did not meet the requirements and there were 10 respondents who met the requirements. So that most of the occupancy humidity of prisoners in the Class 1 Correctional Institution of Lowokwaru Malang does not meet the requirements. It was found that the lighting in the prisoner's residence was around 60 lux. There were 86 respondents whose occupancy lighting did not meet the requirements and there were 10 respondents who met the requirements. So that most of the residential lighting in the Class 1 Lowokwaru Malang Correctional Institution does not meet the requirements.

\subsection{Bivariate analysis}

Based on the bivariate analysis, the physical environment had a significant association with ARI ( $p$-value < 0.05). It included occupancy density, ventilation, temperature, humidity, and lighting of the rooms that were occupied by the respondents. All those indicators were associated with the incidence of ARI in the prison. Smoking behaviour did not showed a significant association with the incidence of ARI ( $p$-value 0.814). The result of bivariate analysis could be seen in Table 3 . 
TABLE 2: Distribution of physical environment characteristics and smoking behaviour.

\begin{tabular}{l|c|c|}
\hline Variable & Number (n) & Percentage (\%) \\
\hline Occupancy density & & \\
\hline Standard & 86 & 89.6 \\
\hline Nonstandard & 10 & 10.4 \\
\hline Ventilation & & \\
\hline Standard & 86 & 89.6 \\
\hline Nonstandard & 10 & 10.4 \\
\hline Temperature & & \\
\hline Standard & 86 & 89.6 \\
\hline Nonstandard & 10 & 10.4 \\
\hline Humidity & & \\
\hline Standard & 86 & 89.6 \\
\hline Nonstandard & 10 & 10.4 \\
\hline Lighting & & \\
\hline Standard & 86 & 10.4 \\
\hline Nonstandard & 10 & \\
\hline Source: Author's own & & \\
\hline
\end{tabular}

Source: Author's own work.

\section{Discussion}

\subsection{Relationship between prison occupancy density and ARI}

The results of the bivariate test analysis showed a significance value ( $p$-value) of 0.001 smaller than the significance level $(\alpha)$ that has been determined in this study, which is 0.05 . The test decision obtained by Ho was rejected, which means that there is a relationship between occupancy density and the incidence of ARI in the Class 1 Prison, Lowokwaru Malang. This is due to the occupancy available with the inmates who occupy it not in accordance with the Ministry of Law and Human Rights (2009) resulting in overcrowding of residents. If the density of the occupancy does not meet the requirements, it can result in the availability of oxygen in the room which is not well fulfilled, resulting in high room temperature and humidity which can cause the growth of disease germs to grow well and facilitate the occurrence of disease transmission both directly and indirectly, especially respiratory diseases.

This research is also in line with research conducted by Taha \& Ryzdayani (2018), that the hot steam produced by the breathing of each occupant is not circulating properly and can also cause a lack of oxygen consumption for each occupant in it, if one occupant is infected with an infectious diseases it will be very easy to infect other residents [5]. 
TABLE 3: Relationship between independent variables and ARI.

\begin{tabular}{|c|c|c|c|c|c|}
\hline \multirow[t]{3}{*}{ Variable } & \multicolumn{4}{|c|}{ ARI } & \multirow[t]{3}{*}{$P$-value } \\
\hline & \multicolumn{2}{|c|}{ Yes } & \multicolumn{2}{|c|}{ Not } & \\
\hline & $n$ & $\%$ & $n$ & $\%$ & \\
\hline \multicolumn{6}{|c|}{ Occupancy density } \\
\hline Nonstandard & 85 & 91.3 & 1 & 33.3 & 0.001 \\
\hline Standard & 8 & 8.8 & 2 & 66.7 & \\
\hline \multicolumn{6}{|l|}{ Ventilation } \\
\hline Nonstandard & 85 & 91.3 & 1 & 33.3 & 0.001 \\
\hline Standard & 8 & 8.8 & 2 & 66.7 & \\
\hline \multicolumn{6}{|l|}{ Temperature } \\
\hline Standard & 85 & 91.3 & 1 & 33.3 & 0,001 \\
\hline Nonstandard & 8 & 8.8 & 2 & 66.7 & \\
\hline \multicolumn{6}{|l|}{ Humidity } \\
\hline Standard & 85 & 91.3 & 1 & 33.3 & 0.001 \\
\hline Nonstandard & 8 & 8.8 & 2 & 66.7 & \\
\hline \multicolumn{6}{|l|}{ Lighting } \\
\hline Standard & 85 & 91.3 & 1 & 33.3 & 0.001 \\
\hline Nonstandard & 8 & 8.8 & 2 & 66.7 & \\
\hline \multicolumn{6}{|c|}{ Smoking behaviour } \\
\hline Light & 49 & 52.6 & 2 & 66.7 & 0.814 \\
\hline Moderate & 35 & 37.6 & 1 & 33.3 & \\
\hline Heavy & 9 & 9.7 & 0 & 0 & \\
\hline
\end{tabular}

Source: Author's own work.

This is also consistent with study conducted by Ahyanti \& Duarsa (2013) that residential density is a factor of ARI [6].

The results of research conducted by Firnanda et al., (2017) explain that if a person lives in a densely populated environment, it can result in the risk of transmission of a very fast disease including ARI [6]. This is also supported by Chen et al., (2014), that occupancy density is a risk factor for acute respiratory disease (ARI) [7].

\subsection{Relationship between ventilation and ARI}

The results of the bivariate test analysis obtained a significance value ( $p$-value) of 0.001 which is smaller than the significance level $(\alpha)$ that has been determined in this study, which is 0.05 . The test decision obtained by Ho was rejected, which means that there is a relationship between ventilation and the incidence of ARI in the Class 1 Prison of Lowokwaru Malang. This means that if a dwelling has adequate ventilation and meets standards, the air circulation in the room can remain good and quality is maintained, 
because the air can circulate every day so that germs that cause diseases, especially respiratory diseases such as ARI can be reduced. This is in accordance with the research conducted by Wulandhani \& Purnamasari (2019) that ventilation is associated with the incidence of ARI [8].

Previous research conducted by Putri \& Mantu (2019), if it has insufficient ventilation, it can cause the lack of toxic oxygen to increase in the room and can cause the humidity of the room to become high due to the process of evaporation of liquid from the skin and its absorption is blocked. Lack of ventilation can cause the exchange of air flow and sunlight from outside the room into the bedroom to be obstructed, making it easier for bacteria that cause ARI disease to grow properly [9].

The statement was in line with the results of research conducted ole h Fitriyah, (2016), that if a room with a ventilation is not good or do not meet the standards and is inhabited by humans, it can cause health disorders, especially disorders penrnapasan, poor ventilation, it can lead to humidity in the room becomes ascended [10]. This is also in line with research conducted by Popow-Kraupp \& Aberle (2011) that the diagnosis of ARI can be caused by ventilation [11].

\subsection{Relationship between temperature and ARI}

The results of the bivariate test analysis obtained a significance value ( $p$-value) of 0.001 which is smaller than the significance level $(\alpha)$ that has been determined in this study, which is 0.05 . The test decision obtained by Ho was rejected, which means that there is a relationship between temperature and the incidence of ARI in the Class 1 Prison, Lowokwaru Malang. This is in accordance with research conducted by [12], the temperature in the room greatly affects the health of family members who inhabit it, if the temperature in the dwelling is low it can cause the growth of bacteria that cause disease to reproduce properly.

Previous research conducted by Juniartha et al., (2014) states that there are several factors that can influence the occurrence of ARI, namely the physical condition of the place of residence, cleanliness, occupancy density, indoor air pollution, ventilation, temperature and lighting in a place of residence affect the occurrence of ARI [13]. This statement is also supported by research conducted by Ardianto \& Yudhastuti, (2012) that the room temperature in the residence can affect the occurrence of ARI disease [14].

This statement is also supported by research conducted by Soolani et al., (2015), which states that temperature is a risk factor that can affect the occurrence of ARI 
disease [15]. This is also supported by a study conducted by [16], that temperature has an effect on the emergence of acute respiratory infections.

\subsection{Relationship between humidity and ARI}

The results of the bivariate test analysis showed a significance value ( $p$-value) of 0.001 smaller than the significance level $(\alpha)$ that has been determined in this study, which is 0.05 . The test decision obtained by Ho was rejected, which means that there is a relationship between humidity and the incidence of ARI in the Class 1 Prison in Lowokwaru Malang. This is in accordance with the research conducted by Nurhayati \& Vera (2019), that a humid occupancy allows animals that cause disease to live in them, such as rats and cockroaches that carry bacteria and viruses, all of which can act as the occurrence of respiratory diseases, humidity in the air house is a good medium for the growth of bacteria that cause ARI [17].

Previous research conducted by Supit et al. (2016) stated that where humidity has an active role in the process of spreading microorganisms in the living environment, if you have a place to live with a low humidity level, it is very easy to overgrow by various germs and bacteria that cause an infectious disease, especially ARI [18] .

This statement is also supported by research conducted by [19], that humidity is one of the risk factors that can cause ARI disease, this is also supported by research conducted by Jalil et al., (2018) that low humidity levels can cause the body is easily dehydrated, which triggers a disease, especially respiratory disease [20].

\subsection{Relationship between lighting and ARI}

The results of the bivariate test analysis obtained a significance value ( $p$-value) of 0.001 which is smaller than the significance level $(\alpha)$ that has been determined in this study, which is 0.05 . The test decision obtained by Ho was rejected, which means that there is a relationship between lighting and the incidence of ARI in the Class 1 Prison in Lowokwaru Malang. This is in line with a study conducted by [21], this lighting is related to ventilation because if the ventilation is lacking, it is rarely opened during the day, does not have home ventilation, it can cause less sunlight to enter the room which can cause the air temperature to be low, humidity increases and so it can cause the growth of pathogenic bacteria in the house which can cause health problems, especially breathing. 
Previous research conducted by [22], stated that lighting is associated with the occurrence of ARI disease. This statement is also supported by research conducted by Syam \& Ronny (2016), that insufficient lighting can prolong the life span of germs in the air [23]. This is also supported by research conducted by Suryani et al., (2015), that there is a significant relationship between natural and artificial lighting on the occurrence of ARI disease [24].

This statement is also in line with research conducted by Saleeby et al., (2011), that lighting can affect the occurrence of Respiratory Infections (ARI), both natural lighting and artificial lighting [25].

\subsection{Relationship between inmates' smoking behaviour and ARI}

The results of the bivariate test analysis obtained a significance value ( $p$-value) of 0.814 which is greater than the significance level $(\alpha)$ that has been determined in this study, which is 0.05 . The test decision obtained by Ho is accepted, which means that there is no relationship between smoking behaviour and the incidence of ARI in the Class 1 Correctional Institution, Lowokwaru Malang. This is also in line with research conducted by Wahyuningsih et al., (2017), which states that there is no relationship between smoking behaviour and the incidence of ARI.

Previous research was also conducted by Imasari et al., (2019), that there was no significant relationship between smoking behaviour and the incidence of ARI even though cigarette smoke has a danger to breathing [27]. This statement is also in line with research conducted by Widodo et al., (2016), which states that the smoking behaviour of families who live in the house has nothing to do with the incidence of ARI [28]. This statement is also supported by research conducted by [29], that smoking behaviour is not associated with the occurrence of Acute Respiratory Infections (ARI).

\section{Conclusion}

This study found that there was a relationship between occupancy density, ventilation, temperature, humidity, lighting, and the incidence of acute respiratory infections in the Class 1 Correctional Institution, Lowokwaru Malang, but it was not found that inmates smoking behaviour was associated with the incidence of acute respiratory infections. 


\section{Acknowledgement}

None

\section{Conflict of Interest}

The authors declare that there is no conflict of interest.

\section{References}

[1] Departemen Hukum dan Hak Asasi Manusia Direktorat Jenderal Pemasyarakatan. (2008). Cetak Biru Pembaharuan Pelaksanaan Sistem Pemasyarakatan. Jakarta: Departemen Hukum dan HAM Direktorat Jenderal Pemasyarakatan bekerja sama dengan Kedutaan Besar Australia-The Asia Foundation-Institute for Criminal Justice Reform (ICJR).

[2] PAS. (2019). Sistem Databese Pemasyarakatan. Retrieved from http://smslap. ditjenpas.go.id/public/grl/current/monthly/kanwil/db61b880-6bd1-1bd1-dd91313134333039 .

[3] Swarjana, I. K. (2015). Metodologi Penelitian Kesehatan. Yogyakarta: CV. Andi Offset.

[4] Notoatmodjo, S. (2012). Metodologi Penelitian Kesehatan. Jakarta: Rineka Cipta.

[5] Taha, L. and Ryzdayani, R. (2018). Kondisi Fisik Rumah Dengan Kejadian Penyakit ISPA di Wilayah Kerja Puskesmas Moncobalang Kecamatan Barombong Kabupaten Gowa. Jurnal Sulolipu: Media Komunikasi Sivitas Akademika dan Masyarakat, vol.18, issue 1, pp. 24-29.

[6] Firnanda, N., Junaid, J. and Jafriati, J. (2017). Analisis Spasial Kejadian Penyakit Infeksi Saluran Pernapasan Akut (ISPA) Pada Balita di Kelurahan Puwatu Tahun 2017. JIMKESMAS: Jurnal IImiah Mahasiswa Kesehatan Masyarakat, vol.2, issue 7, pp. 1-7.

[7] Chen, Y., Kirk, M. D. and Williams, E. (2014). Risk Factors for Acute Respiratory Infection in the Australian Community. PloS ONE, vol.9, issue 7, pp. 1-7.

[8] Wulandhani, S. and Purnamasari, A. B. (2019). Analisis Faktor Risiko Kejadian Infeksi Saluran Pernapasan Akut ditinjau dari Lingkungan Fisik. Jurnal Sainsmat, vol.8, issue 2, pp. 70-81.

[9] Putri, P. and Mantu, M. R. (2019). Pengaruh Lingkungan Fisik Rumah Terhadap Kejadian ISPA pada Balita di Kecamatan Ciwandan Kota Cilegon Periode Juli Agustus 2016. Tarumanagara Medical Journal, vol.1, issue 2, pp. 389-94. 
[10] Fitriyah, L. (2016). Hubungan Kualitas Debu dan Ventilasi Rumah dengan Kejadian Penyakit Infeksi Saluran Pernapasan Atas (ISPA) di Bekas Tempat Pemrosesan Akhir (TPA) Keputih. Jurnal Kesehatan Lingkungan, vol. 8, issue 2, pp. 137-47.

[11] Popow-Kraupp, T. and Aberle, J. (2011). Diagnosis of Respiratory Syncytial Virus Infection. The Open Mycrobiology Journal, vol. 5, issue suppl. 2, pp. 128-34.

[12] Ernyasih, E., Fajrini, F. and Latifah, N. (2018). Analisis Hubungan Iklim (Curah Hujan, Kelembaban, Suhu Udara dan Kecepatan Angin) dengan Kasus ISPA di DKI Jakarta Tahun 2011 - 2015. Jurnal IImu Kesehatan Masyarakat, vol. 7, issue 3, pp. 167-73.

[13] Juniartha, S. K., Hadi, H. M. C. and Notes, N. (2014). Hubungan Antara Luas dan Posisi Ventilasi Rumah Dengan Kejadian ISPA Penghuni Rumah di Wilayah Puskesmas Bangli Utara Tahun 2012. Jurnal Kesehatan Lingkungan, vol. 4 no. 2, pp. 169-147.

[14] Ardianto, Y. D. and Yudhastuti, R. (2012). Kejadian Infeksi Saluran Pernapasan Akut pada Pekerja Pabrik. Jurnal Kesehatan Masyarakat Nasional, vol. 6, issue 5, pp. 230-3.

[15] Soolani, D. C., Umboh, J. M. L. and Akili, R. H. (2015). Hubungan antara Faktor Lingkungan Fisik Rumah dengan Kejadian Infeksi Saluran Pernapasan (ISPA) pada Balita di Kelurahan Malalayang 1 Kota Manado. KESMAS, vol. 5, issue 2, pp. 1-8.

[16] Tang, J. W.-T. and Loh, T. P. (2014). Correlations Between Climate Factors and Incidence-a Contributor to RSV Seasonality. Medical Virology, vol. 24, issue 1, pp. 15-34.

[17] Nurhayati, N. and Vera, V. (2019). Hubungan Antara Kondisi Fisik Rumah Dengan Kejadian Infeksi Saluran Pernapasan Atas (ISPA) Di Wilayah Puskesmas Curug Kabupaten Tangerang. Prosiding Seminar Nasional Pakar Ke 2 Tahun 2019, vol. 1, issue 1, pp. 1-12.

[18] Supit, A. F., Joseph, W. B. S. and Kaunang, W. P. J. (2016). Hubungan Antara Lingkungan Fisik Rumah Dengan Kejadian Penyakit Infeksi Saluran Pernapasan Akut Pada Balita Di Desa Talawaan Atas Dan Desa Kima Bajo Kecamatan Wori Kabupaten Minahasa Utara. Pharmacon, vol. 5, issue 2, pp. 259-65.

[19] Stewart, P. D. S. (2015). Seasonality and Selective Trends in Viral Acute Respiratory Tract Infections. Medical Hypotheses, vol. 86, issue 1, pp. 104-19.

[20] Jalil, R., Yasnani, Y. and Sety, L. O. M. (2018). Faktor-Faktor Yang Berhubungan Dengan Kejadian Ispa Pada Balita Di Wilayah Kerja Puskesmas Kabangka Kecamatan Kabangka Kabupaten Muna Tahun 2018. JIKMESMAS: Jurnal IImiah Mahasiswa Kesehatan Masyarakat, vol. 3, issue 4, pp. 1-5. 
[21] Triandriani, V. and Hansen, H. (2019). Hubungan Lingkungan Fisik dengan Kejadian Ispa pada Balita di Wilayah Kerja PUSKESMAS Sidomulyo Kota Samarinda. Borneo Student Research (BSR), vol. 1, issue 1, pp.146-51.

[22] Bee, L. W., Akili, R. H. and Sinolungan, J. V. S. (2014). Hubungan Antara Kondisi Lingkungan Fisik Rumah Dengan Kejadian Infeksi Saluran Pernapasan Akut (Ispa) Pada Anak Balita Di Wilayah Kerja Puskesmas Salibabu Kabupaten Kepulauan Talaud Tahun 2014. KESMAS, vol. 4, issue 2, pp. 29-35.

[23] Syam, D. M. and Ronny, R. (2016). Suhu, Kelembaban dan Pencahayaan Sebagai Faktor Risiko Kejadian Penyakit ISPA Pada Balita di Kecamatan Balaesang Kabupaten Donggala. HIGIENE: Jurnal Kesehatan Lingkungan, vol. 2, issue 3, pp.133-9.

[24] Suryani, I., Edison, E. and Nazar, J. (2015). Hubungan Lingkungan Fisik dan Tindakan Penduduk dengan Kejadian ISPA pada Balita di Wilayah Kerja Puskesmas Lubuk Buaya. Jurnal Kesehatan Andalas, vol. 4, issue 1 pp. 157-67.

[25] Saleeby, C. M. E., Bush, A. J., Harrison, L. M., Aitken, J. A. and DeVicenzo, J. P. (2011). Respiratory Syncytial Virus Load, Viral Dynamics, and Disease Severity in Previously Healthy Naturally Infected Children. The Journal of Infectious Diseases, vol. 204, issue 7, pp. 996-1002.

[26] Wahyuningsih, S., Raodhah, S. and Basri, S. (2017). Infeksi Saluran Pernafasan Akut (ISPA) pada Balita di Wilayah Pesisir Desa Kore Kecamatan Sanggar Kabupaten Bima, HIGIENE: Jurnal Kesehatan Lingkungan, vol. 3, issue 2, pp.97-105.

[27] Imasari, T., Mu'arofah, B. and Pati, B. F. (2019). Korelasi Perilaku Merokok Terhadap Jumlah Pertumbuhan Bakteri Kokus di Bandar Lor Kota Kediri. JUDIKA: Jurnal Nusantara Medika, vol.3, issue 1, pp. 23-9.

[28] Widodo, Y. P., Dewi, R. C. and Saputri, L. D. (2016). Hubungan Perilaku Keluarga Terhadap Kejadian Infeksi Saluran Pernafasan Atas (ISPA). Jurnal IImu Kesehatan Bhamada, vol.7, issue 2, pp. 103-13.

[29] Branche, A. R. and Falsey, A. R. (2015). Respiratory Syncytial Virus Infection in Older Adults: An Under-Recognized Problem. Drugs \& Aging, vol. 32, issue 4, pp. 261-69. 